\title{
The Effects of Shopping Orientations, Consumer Innovativeness, Purchase Experience, and Gender on Intention to Shop for Fashion Products Online*
}

\author{
Ratih Puspa Nirmala \\ Master of Management, Faculty of Economics and Business, Universitas Gadjah Mada, Yogyakarta \\ Ike Janita Dewi \\ Master of Management, Faculty of Economics and Business, Universitas Gadjah Mada, Yogyakarta
}

\begin{abstract}
Nowadays, many fashion retailers or marketers use the power of internet to promote and sell their products. This research examines the effects of consumers' shopping orientations (brand/fashion consciousness, shopping enjoyment, price consciousness, convenience/time consciousness, shopping confidence, in-home shopping tendency), consumer innovativeness, online purchase experience for fashion products, and gender on consumers' intention to shop for fashion products online. Data were collected through online surveys from the population of internet users in Indonesia, aged between 15 and 30 years old (generation $\mathrm{Y}$ ), who had bought or browsed fashion products through the internet $(\mathrm{N}=210)$. This research is a quantitative research which uses purposive sampling and multiple regression analysis. Results show that the effects of several shopping orientations (shopping enjoyment, price consciousness, inhome shopping tendency), consumer innovativeness, online purchase experience for fashion products, and gender, are significant on consumers' intention to shop for fashion products online. Furthermore, gender is marginally significant related to consumers' intention to shop for fashion products online. Surprisingly, women tend to have lower intentions to shop for fashion products online compared to men.
\end{abstract}

\begin{abstract}
Abstrak: Dewasa ini, terdapat sebuah fenomena yang menunjukkan bahwa semakin banyak peritel produk pakaian yang menggunakan internet untuk mempromosikan dan menjual produknya. Penelitian ini menguji apakah orientasi-orientasi konsumen dalam berbelanja pakaian (brand/ fashion consciousness, shopping enjoyment, price consciousness, convenience/ time consciousness, shopping confidence, in home shopping tendency), keinovatifan konsumen, pengalaman pembelian produk pakaian secara online, dan jender secara signifikan mempengaruhi dengan niat belanja produk pakaian secara online. Data dikumpulkan melalui survei online terhadap populasi pengguna internet di Indonesia yang berusia 15 sampai dengan 30 tahun, yang telah membeli atau melihatlihat produk pakaian melalui internet. Penelitian ini merupakan penelitian kuantitatif yang menggunakan purposive sampling dan analisis regresi berganda. Hasil penelitian menunjukkan bahwa beberapa orientasi
\end{abstract}

*This paper is part of Ratih Puspa Nirmala's master thesis.

Corresponding authors. E-mail: ikejanitadewi@yahoo.com

ISSN: $1141-1128$

http://www.gamaijb.mmugm.ac.id/ 
belanja (shopping enjoyment, price consciousness, in-home shopping tendency), keinovatifan konsumen, pengalaman pembelian produk pakaian secara online, dan jender secara signifikan mempengaruhi niat belanja produk pakaian secara online. Selain itu, hasil yang mengejutkan menunjukkan bahwa dibandingkan dengan lakilaki, ternyata perempuan memiliki niat belanja produk pakaian secara online yang lebih rendah, walaupun hanya signifikan secara marjinal.

Keywords: consumer innovativeness; fashion; online shopping intention; purchase experience; shopping orientations 


\section{Introduction}

Nowadays, many fashion retailers or marketers use the power of internet to promote and sell their products. In Indonesia, the internet users in 2007 reached 25 million people and ranked the fifth largest in Asia, under China, Japan, India, and South Korea (internetworldstats.com 2009).

Nielsen Global Online Survey (2008) showed that clothing/accessories/shoes (fashion products) were one of the most popular purchases online. This fact motivates researchers to further examine fashion online shopping, because it is a new phenomenon for many customers. There are some individuals who are interested in shopping online for fashion products, however, although fashion product is a product that consumers will feel more comfortable if they can try the products prior to purchase. We argue that such market behavior can be explained by consumer characteristics of shopping orientation, consumer innovativeness, purchase experience, and gender.

Several researchers in other countries have examined the relationship of shopping orientation and online purchases (Brown et al. 2003; Girard et al. 2003; Seock 2003; Seock and Bailey 2008; Vijayasarathy 2003). One research shows that the effect of shopping orientation on intention to shop can be different for different kinds of products (Vijayasarathy 2003). Research conducted by Seock (2003) shows the relationship of one's shopping orientation with the intention to buy fashion product can be different for every distribution channel.

There is one trait that affects online shopping-, consumer's innovativeness. Consumer innovativeness has a significant influence on online shopping success (Alcañiz et al. 2008). Previous research conducted overseas has examined such a relationship of innovativeness and online shopping intention (Blake et al. 2003; Citrin et al. 2000; Goldsmith 2002).

There is other research that shows how previous online shopping experienceaffects future intention to shop (Goldsmith 2002; Jayawardhena et al. 2007; Seock 2003). Other research shows the effect of gender on online shopping intention and behavior (Brown et al. 2003; Jayawardhena et al. 2007; Vijayasarathy 2003). Previous research has focused only on relationships of psychographics with generic product shopping (Brown et al. 2003; Vijayasarathy, 2003), both psychographics and demographic factors with generic shopping on internet (Girard et al. 2003), and some psychological and behavioral factors that influence online clothing purchase (Goldsmith and Flynn 2004). Therefore, this present research is needed to synthesize previous research to find out about the effects of psychographics, demographic, and behavioral characteristics specifically on online fashion product shopping. Findings from this research will provide evidence on the full arrays of influence of consumer characteristics on their online purchase intention for fashion products.

Furthermore, the research mentioned above is research conducted outside Indonesia. The result might be different if it were carried out in Indonesia. Kuhlmeier and Knight (2004) state that results from e-commerce studies might not be applicable across countries, partly because there is a difference in the level of technology diffusion around the world. Further, the emergence of online stores is a new phenomenon in Indonesia. Insights from this research will help managers in planning and formulating marketing 
strategy in promoting fashion product through online shopping in Indonesia.

The aim of this research is to examine the effects of consumers' shopping orientations (brand/fashion consciousness, shopping enjoyment, price consciousness, convenience/time consciousness, shopping confidence, in-home shopping tendency), consumer innovativeness, online purchase experience for fashion products, and gender on consumers' intention to shop for fashion products online in Indonesia.

This research can enrich empirical research about e-marketing, especially in Indonesia. Research results can benefit marketers, especially fashion product marketers to develop effective marketing strategies. By understanding consumer characteristic, marketers can segment and target consumers who will communicate positively about product offered. Maximum consumer satisfaction can also be achieved. Insights about factors that affect someone's intention to shop through internet can be a valuable foundation in exploring new online business opportunities.

\section{Theoretical Background and Hypotheses Development}

\section{Intention to Shop for Fashion Products Online}

Purchase intention refers to a mental state that reflects the consumer's decision to acquire a product or service in the immediate future (Howard, in Alcañiz et al. 2008). In the context of virtual shopping, this would be the decision to use the internet as a new shopping channel (Alcañiz et al. 2008). Vijayasarathy (2002) said that shopping, which includes purchase, also encompasses the acts of browsing, comparing, evaluating and decision making.

\section{Clothing shopping orientations}

Clothing shopping orientations are categories of shopper styles with particular emphasis on clothing shopping activities, reflecting consumer needs or wants when shopping for and/or purchasing clothing products (Seock 2003). There are some previous researches done to examine the effects of shopping orientations on online shopping intention (Girard et al. 2003; Jayawardhena et al. 2007; Seock 2003; Seock and Bailey 2008; Vijayasarathy 2003). In this research we will examine the effect of several shopping orientations on intention to shop for fashion products online, which will be explained in sub-chapters below.

\section{Brand/fashion consciousness}

Brand/fashion consciousness is a tendency of consumers to be oriented on brand name or fashion trends. Seock and Bailey (2008) found that brand/fashion consciousness was significantly and positively related to both information searches and purchases online. Consumers with brand/fashion consciousness may visit apparel websites to check the latest styles and new fashion trends. If they find the products they like, they may purchase those items online. Thus, our first hypothesis is:

\section{H1: Brand/fashion consciousness has a positive effect on intention to shop for fashion products online.}

\section{Shopping enjoyment}

Shopping enjoyment is a tendency of consumers to enjoy shopping for clothes. Seock and Bailey (2008) found that shopping enjoyment was significantly and positively related to both information searches and 
purchases online. Consumers with shopping enjoyment attain pleasure from shopping and spending time browsing for apparel items. Thus, our second hypothesis is:

\section{H2: shopping enjoyment has a positive effect on in-} tention to shop for fashion products online.

\section{Price consciousness}

Price consciousness is a tendency of consumers to be oriented on price when shopping for clothes. Seock and Bailey (2008) found that price consciousness was positively related to information searches online, but negatively related to the purchases of apparel items online. Consumers with price consciousness are concerned about price and, therefore, pay a great deal of attention to apparel prices. Consumers with price consciousness may visit: iternet web sites to find out about sales or promotional deals or to compare prices from different companies' websites. Similar to that result, Vijayasarathy (2003) found that this orientation was significantly and positively influencing internet shopping intention. Thus, the third hypothesis is:

H3: Price consciousness has a positive effect on intention to shop for fashion products online.

\section{Convenience/time consciousness}

Convenience/time consciousness is a tendency of consumers to be oriented on convenience or time when shopping for clothes. Seock and Bailey (2008) stated that consumers with convenience/time consciousness are concerned about time when shopping, and tend to shop for clothes at stores where they save time. Stell and Paden (2002) said that the convenience shopper is interested foremost in saving time and effort during the shopping experience. These individuals are looking for a means of expediting and simplifying the purchase process. This category of shopper also includes individuals charac- terized as time-pressured or time-poor, who, because of the situation, have a need to make purchases with a minimum of effort and time.

Some researchers showed that convenience was an important motivational factor in online shopping (Szymansky and Hise 2000). Girard et al. (2003) found that convenience was positively related to preference for shopping on the Internet, and it was a strong predictor for preference to shop on the internet for the experience- products such as clothing and perfume. Thus, the fourth hypothesis is:

H4: Convenience/time consciousness has a positive effect on intention to shop for fashion products online.

\section{Shopping confidence}

Shopping confidence is a tendency of consumers to be confident when shopping for clothes. Seock and Bailey (2008) found that shopping confidence was significantly and positively related to the purchase of apparel items online. Consumers who have confidence in their shopping abilities may purchase apparel items online. Some consumers may be reluctant to buy products online because of an inability to experience the products through the websites. However, if the consumers become more assured of their abilities to shop for apparel items and select the right products for themselves, they may be less hesitant to purchase apparel items online. Thus, the fifth hypothesis is:

\section{H5: Shopping confidence has a positive effect on in-} tention to shop for fashion products online.

\section{In-home shopping tendency}

In-home tendency is a tendency of consumers to shop for clothes from home. Seock and Bailey (2008) found that in-home shopping tendency was positively related to both searching online for information about ap- 
parel products and purchasing such items online. Thus, the sixth hypothesis is:

\section{H6: In-home shopping tendency has a positive effect on intention to shop for fashion products online.}

\section{Consumer Innovativeness}

Innovativeness is a personality trait that underlies the adoption of innovation (Leavitt and Walton 1975, 1988). Trait is the basis of a stable trend over time; it varies among individuals and influences behavior (Matthews et al. 2003). Furthermore, Hurt et al. (1997) define innovativeness as a desire to change, be innovative and try new things (Goldsmith 2002, Roehrich 2004, Tellisto: et al. 2009). Goldsmith (2002) argued that innovativeness is a personality construct that is owned, to a level higher or lower, by all individuals because everyone at some point in their lives or the object will adopt new ideas.

An innovator is described as an individual who is open to new experiences and stimulation; has the ability to modify information about new concepts, ideas, products or services for own use and has a low threshold for recognizing the potential application of new ideas (Leavitt and Walton 1975, 1988). In the context of business and marketing, consumer innovativeness is closely related to the adoption of a product (Alcañiz et al. 2008). This affects the speed with sustainability adoption after a product enters the market (Goldsmith and Flynn 1992).

Therefore, consumer innovativeness has had a huge impact in the success of shopping via the internet (Alcañiz et al. 2008). Results of the research showed that online shopping innovativeness directly and positively affects both the search for information before buying products online, and the decision to buy through the internet (Blake et al. 2003; Citrin et al. 2000; Goldsmith 2002;
Goldsmith and Flynn 2004). Citrin et al. (2000) showed that innovativeness along with internet usage directly affects consumer behavior to adopt shopping via the internet. These results are supported by Limayem et al. (2000) showing that innovativeness influences shopping behavior through the Internet. Thus the seventh hypothesis is:

H7: Consumer innovativeness has a positive effect on intention to shop for fashion products online.

\section{Purchase Experience}

Previous research showed that previous experience in shopping affects future shopping behavior. (Shim et al. 2001). In that study, the experience of purchasing via the internet affected the intention to seek information and buy products via the internet. Jayawardhena et al. (2007) showed that the consumer's previous online shopping experience will have a significant effect on their future purchase intention for online shopping. In other words, if someone ever bought a product online then the experience will affect their intention to purchase products online. Furthermore, a result of the research conducted by Ranganathan and Jha (2007) showed that the experience of shopping through the website in the past has a strong influence on the intention to make online purchasing in the future. Thus, the eighth hypothesis is:

H8: Purchase experience has a positive effect on intention to shop for fashion products online.

\section{Gender}

In this study, "gender" is to replace "sex." The results of the study showed that gender has effect on intentions to buy products online (Jayawardhena et al. 2007; Vijayasarathy 2003). Vijayasarathy (2003) showed that younger males with a higher 
Figure 1. Relationships Between Variables

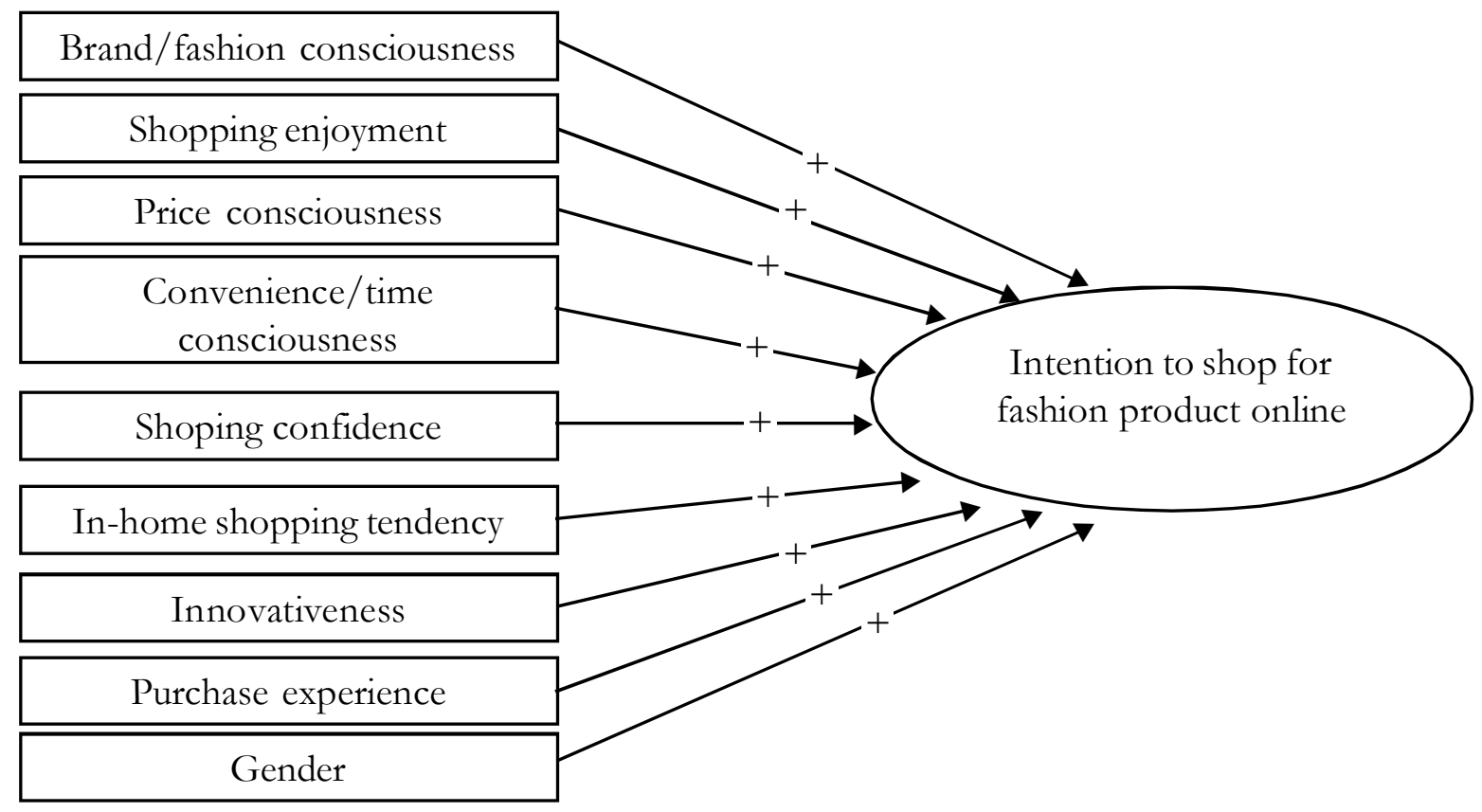

household income would be more likely to engage in internet shopping. In contrast to Vijayasarathy (2003), other researchers showed that women are more likely to shop for clothing products online than men (Girard et al. 2003; Goldsmith and Flynn 2004). Girard et al. (2003) showed that gender was the most common predictor for preference for shopping online. Specifically, more men preferred to shop online for books, personal computers, cellular phones and television whereas more women preferred to shop online for clothing and perfumes. A study by Kim and Kim (2004) also showed that gender was a significant predictor in determining consumers' online purchase intentions for clothes, jewelery or accessories, and that female consumers showed greater online purchase intentions for clothes, jewelery and accessories than male consumers. Results show that men tend to buy CDs, music downloads, DVDs, books, computer and electrical products whereas women favor clothing, footwear, lin- gerie and accessories (Allegra Strategies; IMRG; in Jayawardhena et al. 2007). Thus, the ninth hypothesis is:

H9: Women are more likely to have intention to shop for fashion products online than men.

\section{The Research Model}

The research model which depicts all the hypothesized relationships is as Figure 1.

\section{Methodology}

\section{Type of Research and Data Collection}

This research is a quantitative research. The research is designed as a formal study (by the degree to which the research question has been crystallized) and as a causal study (by purposes of the research) and (Cooper and Schindler 2009). We employ purposive sampling and multiple regression analy- 
sis. The research SPSS was used to analyze the data. Validity and reliability testing were conducted before the hypothesis testing.

The content validity of the questionnaire was assessed through examination by an expert at the university and through pilot testing with 5 respondents which met the sample criteria. Some changes were made in order to clarify the instructions and questions according to recommendations and comments. The construct validity was assessed through total-item correlation. The item of the construct is valid if corrected total-item correlation $>0.2$ (Garret 1960). To asses the reliability, we used internal consistency using cronbach's alpha. A value of 0.6 or less generally indicates unsatisfactory internal consistency reliability (Malhotra 2004). Prior to conducting the multiple regression analysis, tests of the regression assumptions (multicollinearity, homoscedasticity, and normality of residuals) were performed.

A multiple regression analysis was performed to assess the relative influence of the independent variables (brand/fashion consciousness, shopping enjoyment, price consciousness, convenience/time consciousness, shopping confidence, in-home shopping tendency, consumer innovativeness, purchase experience, and gender) on the dependent variable (intention to shop for fashion products online).

The regression equation of the relationships is as follows:

$$
\begin{aligned}
Y= & a+b_{1} X_{1}+b_{2} X_{2}+b_{3} X_{3}+b_{4} X_{4}+ \\
& b_{5} X_{5}+b_{6} X_{6}+b_{7} X_{7}+b_{8} X_{8}+b_{9} X_{9}+e
\end{aligned}
$$

where:

$\mathrm{a}=$ constant

$\mathrm{X} 1=\mathrm{brand} /$ fashion consciousness

$\mathrm{X} 2=$ shopping enjoyment

$\mathrm{X} 3=$ price consciousness

$\mathrm{X} 4=$ convenience/time consciousness

$\mathrm{X} 5=$ shopping confidence

$\mathrm{X} 6=$ in-home shopping tendency

$\mathrm{X} 7=$ innovativeness

$\mathrm{X} 8=$ purchase experience

$\mathrm{X} 9=$ gender

$\mathrm{Y}=$ Intention to shop for fashion product online

Data were collected through online surveys from the population of internet users in Indonesia, aged between 15 and 30 years old when this research was conducted (generation Y), who had bought or browsed fashion products (such as t-shirt/shirt, pants, shoes, hat, bag, accessories) at online stores (such as websites, Facebook, Kaskus, Multiply, blog).

Data collection was conducted for 10 days (February 1-10, 2010). An incentive was offered for answering the questionnaire through a blind, randomized price drawing, and would be given to 2 winners, IDR 150.000 each. Winners of the drawing were notified through the website that had been prepared and by phone.

The constructs were measured by multiitem scales chosen because they have been used previously and have demonstrated good psychometric characteristics. 


\section{Dependent Variable}

Intention to shop for fashion products online was measured using four items developed by Vijayasarathy (2003), which were modified for the purpose of this research. Respondents were asked to rate their responses on a five point Likert scale $(1=$ strongly disagree to $5=$ strongly agree) Those items were: "I intend to use the internet to shop for fashion products," "I plan to do more of my shopping for fashion products using the internet," "I intend to use the internet to collect information about fashion products," and "I probably will shop for fashion products using the internet in the near future." Corrected item total correlations ranged from 0.333 to 0.749 . Coefficient alpha was 0.792 .

\section{Independent Variables}

We used instruments developed by Seock (2003). Respondents were asked to rate their responses on a five point Likert scale $(1=$ strongly disagree to $5=$ strongly agree $)$ corresponding brand/fashion consciousness (5 items), shopping enjoyment (4 items), price consciousness (6 items), convenience/time consciousness ( 3 items), shopping confidence (3 items) and in-home shopping tendency ( 3 items).

For brand/fashion consciousness, among the 5 items, 1 item was not valid: "I'm interested in fashion." 4 items were retained for the hypothesis testing. Those items were: "I like to buy popular brands of clothing," "I try to keep my wardrobe up to date with fashion trends," "A well-known brand means good quality," and "I don't pay much attention to brand names (reverse coded)."Corrected item total correlations ranged from 0.317 to 0.509 . Coefficient alpha was 0.625 .
For shopping enjoyment, the items were: "Shopping for clothes puts me in a good mood," "I enjoy shopping for clothes," "I enjoy spending time browsing for clothes," and "I don't like to spend much time shopping for clothe”s (reverse coded)." Corrected item total correlations ranged from 0.565 to 0.719 , while the coefficient alpha was 0.835 .

For price consciousness, among the 6 items, we deleted 3 items ("I shop a lot for special deals on clothing," "I can save a lot of money on clothes by shopping around for bargains," and "I watch advertisements for sales on clothing") because they were not valid..Therefore, 3 items were retained for the hypothesis testing: "I pay a lot of attention to clothing prices," "When I find clothes I like, I usually buy them without hesitation (reverse coded)," and "I don't mind paying high prices for clothes (reverse coded). Corrected item total correlations for the six items ranged from 0.346 to 0.536 . Coefficient alpha was 0.611.

For convenience/time consciousness, the items were: "I usually buy my clothes at the most convenient place," "I shop for clothes where it saves time," and "I put a high value on convenience when shopping for clothes. Corrected item total correlations ranged from 0.603 to 0.670 . The scale's coefficient alpha was 0.785 .

For shopping confidence, the items were: "I feel confident in my ability to shop for clothes," "I think I'm a good clothing shopper," and "I am able to choose the right clothes for myself." Corrected item total correlations ranged from 0.516 to 0.669 , while the coefficient alpha was 0.762 .

For the construct of In-home shopping tendency, the items were "I like to shop for clothes by mail, telephone or the Internet," 


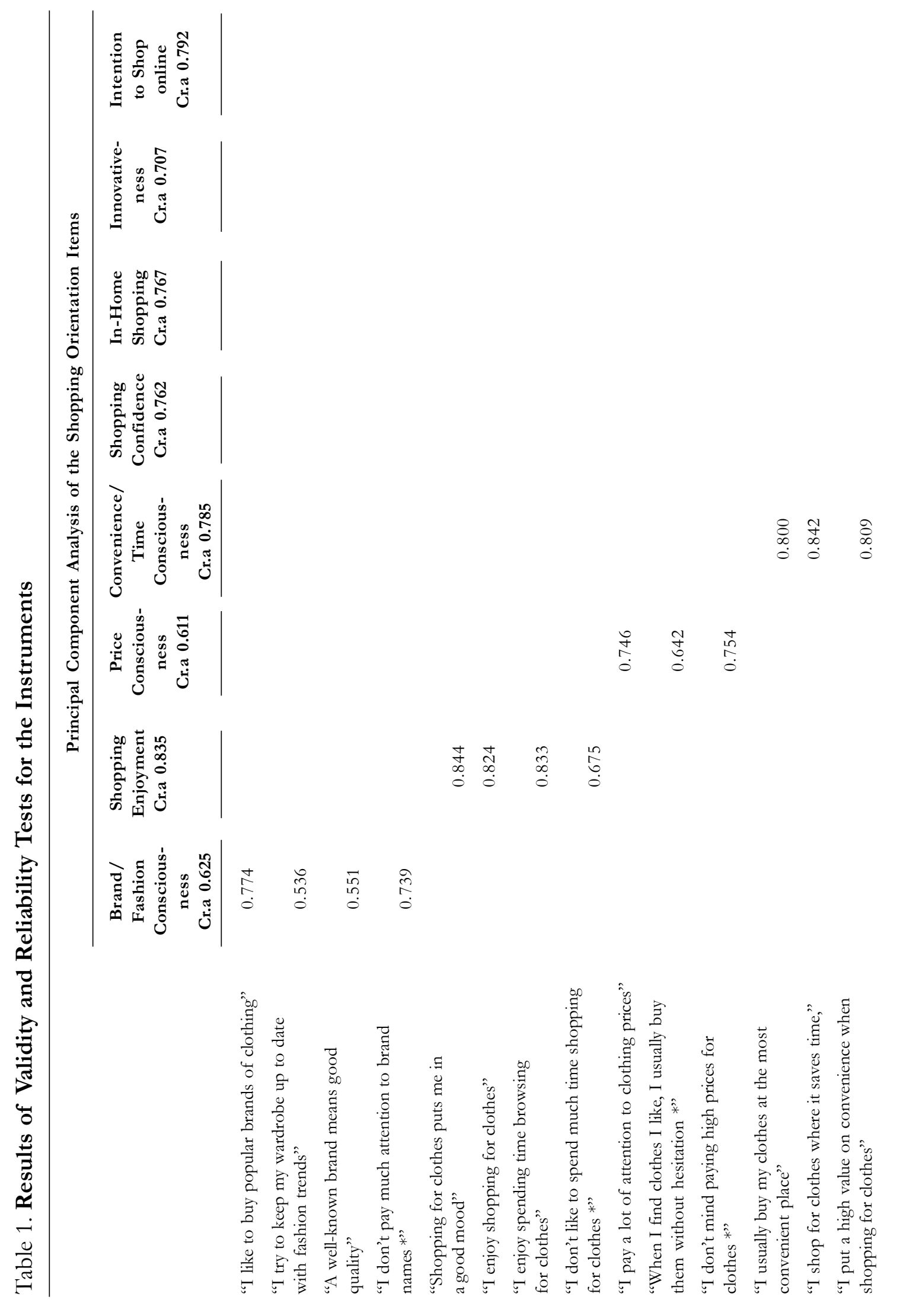


Gadjah MadaInternational Journal of Business -January-April, Vol.13,No. 1,2011

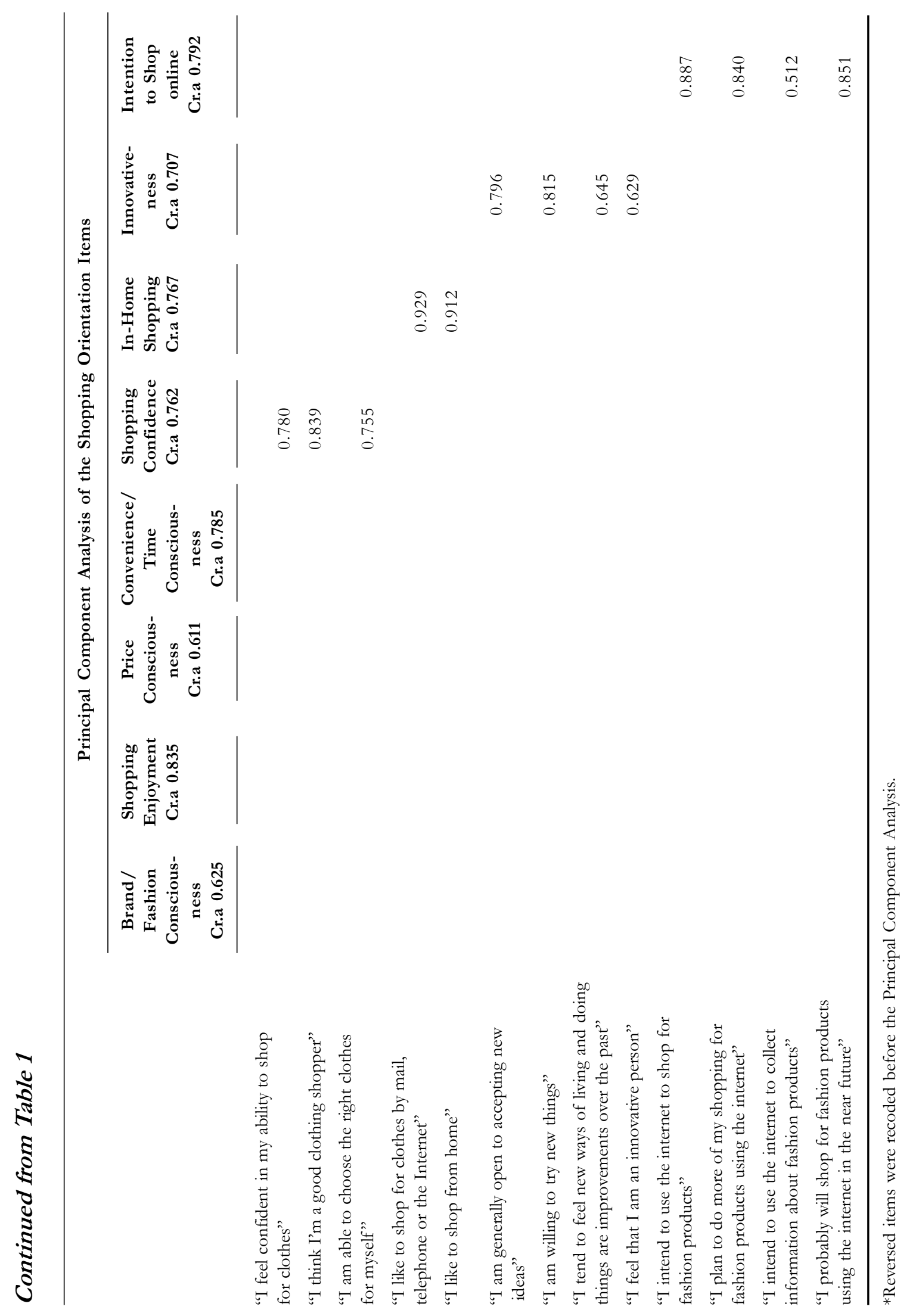


"I like to shop from home." Coefficient alpha was 0.868 . Corrected item total correlation was 0.767 .

Consumer innovativeness was measured using 4 items of global innovativeness, which was adapted by Goldsmith (2002) from the original scales developed by Hurt et al. (1977). Respondents were asked to rate their responses on a five point Likert scale ( $1=$ strongly disagree to $5=$ strongly agree) corresponding consumer innovativeness. The items were: "I am generally open to accepting new ideas," "I am willing to try new things," "I tend to feel new ways of living and doing things are improvements over the past," and "I feel that I am an innovative person." Corrected item total correlations ranged from 0.419 to 0.578 . Coefficient alpha was 0.707 .

In this research, only 1 item represents purchase experience, adapted from Seock (2003). The item was: "Over the past 12 months, about how much did you buy clothes on the Internet?" A five-point scale was used, ranging from (1) "never" to (5) "very often." While all items were calculated on their corrected total-item correlation, we conducted a factor analysis to re-examine the construct validity of the measures. Results of the factor analysis as well as results of the internal consistency test or cronbach alpha scores are presented in Table 1. Gender was coded into dummy variables, i.e., $1=$ female; $0=$ male.

\section{Results and Implication}

\section{Profile of Respondents}

Of the 263 responses, 210 were used in the data analysis because they met the sample criteria (aged 15-30, had bought or browsed fashion products through internet, and live in Indonesia). Of 210 respondents, $162(77.2 \%)$ respondents who had already bought product or service through the internet and 123 respondents had already bought fashion products. The respondents who had bought products or services through the internet were asked about the payment method they used when purchasing online. Multiple answers could be chosen.

Table 2.Demographic Profile of the Respondents

\begin{tabular}{|c|c|c|}
\hline Variable & $\mathbf{N}$ & $\%$ \\
\hline \multicolumn{3}{|l|}{ Gender } \\
\hline Men & 96 & 45.7 \\
\hline Women & 114 & 54.3 \\
\hline \multicolumn{3}{|l|}{ Age } \\
\hline $15-19$ & 46 & 21.9 \\
\hline $20-24$ & 91 & 43.3 \\
\hline $25-30$ & 73 & 34.8 \\
\hline \multicolumn{3}{|l|}{ Marital status } \\
\hline Single & 192 & 91.4 \\
\hline Married & 18 & 8.6 \\
\hline \multicolumn{3}{|l|}{ Residence } \\
\hline Jakarta & 155 & 73.8 \\
\hline Outside Jakarta & 55 & 26.2 \\
\hline \multicolumn{3}{|l|}{ Education } \\
\hline High school & 38 & 18.1 \\
\hline Diploma & 24 & 11.4 \\
\hline Bachelor & 120 & 57.1 \\
\hline Master & 28 & 13.3 \\
\hline \multicolumn{3}{|l|}{$J o b$} \\
\hline Student & 111 & 52.9 \\
\hline Employee, etc & 99 & 47.3 \\
\hline \multicolumn{3}{|l|}{ Income } \\
\hline$<$ IDR 500.000 & 40 & 19 \\
\hline IDR 500.000-IDR 999.999 & 40 & 19 \\
\hline IDR 1.000.000-IDR 2.999.999 & 72 & 34.3 \\
\hline IDR 3.000.000-IDR 5.000.000 & 34 & 16.2 \\
\hline$>$ IDR 5.000 .000 & 24 & 11.4 \\
\hline
\end{tabular}


Results show that payment by way of transfer by bank or ATM card was commonly used by respondents (130 respondents). Twenty six (26) respondents used m-banking/internet banking, 25 respondents used credit cards, 18 respondents used cash on delivery method, and 15 respondents used PayPal/alertpay/liberty reserve. The demographic profile of the sample is presented in Table 2.

\section{Descriptive Statistics}

The mean values and standard deviation for each of the variable are shown in Table 3. Results show that mean value for brand fashion consciousness is $\mathrm{X}_{\text {total }}=2.8655$ where male respondents scored higher than their female counterparts $\left(\mathrm{X}_{\text {male }}=2.9635\right.$ vs $\left.\mathrm{X}_{\text {female }}=2.7829\right)$. The male respondents also scored higher in terms of convenience/time conscious $\left(\mathrm{X}_{\text {male }}=3.7465\right.$ vs $\mathrm{X}_{\text {female }}=3.6901$, while $\left.\mathrm{X}_{\text {total }}=3.7159\right)$, in-home shopping tendency $\left(\mathrm{X}_{\text {male }}=2.8906\right.$ vs $\mathrm{X}_{\text {female }}=2.6974$, while $\left.\mathrm{X}_{\text {total }}=2.7857\right)$ and innovativeness $\left(\mathrm{X}_{\text {male }}=\right.$ 4.0729 vs $\mathrm{X}_{\text {female }}=3.9298$, while $\mathrm{X}_{\text {total }}=$ 3.9952). Further, the mean value of shopping enjoyment is $\mathrm{X}_{\text {total }}=3.7083$ where female respondents' mean value is higher than male respondents' $\left(\mathrm{X}_{\text {female }}=3.7083\right.$ vs. $\mathrm{X}_{\text {male }}=$ 2.8854). Female respondents also scored higher in terms of price consciousness $\left(\mathrm{X}_{\text {female }}=3.2895\right.$ vs. $\mathrm{X}_{\text {male }}=3.2847$, while

Table 3. Descriptive Statistics: Mean Values and Standard Deviation of Scores for Each Variable

\begin{tabular}{|c|c|c|c|c|c|c|}
\hline & Gender & $\begin{array}{c}\text { Brand/ } \\
\text { fashion } \\
\text { Consciousness }\end{array}$ & $\begin{array}{l}\text { Shopping } \\
\text { Enjoyment }\end{array}$ & $\begin{array}{c}\text { Price } \\
\text { Consciousness }\end{array}$ & $\begin{array}{c}\text { Convenience/ } \\
\text { time } \\
\text { Consciousness }\end{array}$ & \\
\hline \multirow[t]{2}{*}{ Male } & Mean & 2.9635 & 2.8854 & 3.2847 & 3.7465 & \\
\hline & $S D$ & 0.65291 & 0.84130 & 0.77983 & 0.78695 & \\
\hline \multirow[t]{2}{*}{ Female } & Mean & 2,7829 & 3.7083 & 3.2895 & 3.6901 & \\
\hline & $S D$ & 0.65134 & 0.69282 & 0.66889 & 0.64526 & \\
\hline \multirow[t]{4}{*}{ Total } & Mean & 2.8655 & 0.3321 & 3.2873 & 3.7159 & \\
\hline & $S D$ & 0.65672 & 0.86608 & 0.71996 & 0.71232 & \\
\hline & & & In-home & & & \\
\hline & Gender & $\begin{array}{l}\text { Shopping } \\
\text { Confidence }\end{array}$ & $\begin{array}{l}\text { Shopping } \\
\text { Tendency }\end{array}$ & Innovativeness & $\begin{array}{c}\text { Purchase } \\
\text { Experience }\end{array}$ & $\begin{array}{l}\text { Purchase } \\
\text { Intention }\end{array}$ \\
\hline \multirow[t]{2}{*}{ Male } & Mean & 3.7361 & 2.8906 & 4.0729 & 2.1458 & 3.3177 \\
\hline & $S D$ & 0.68041 & 1.05682 & 0.57230 & 1.08559 & 0.73223 \\
\hline \multirow[t]{2}{*}{ Female } & Mean & 3.8421 & 2.6974 & 3.9298 & 2.0175 & 3.1535 \\
\hline & $S D$ & 0.65056 & 1.02322 & 0.43302 & 1.13654 & 0.69409 \\
\hline \multirow[t]{2}{*}{ Total } & Mean & 3.7937 & 2.7857 & 3.9952 & 2.0762 & 3.2286 \\
\hline & $S D$ & 0.66488 & 1.04070 & 0.50533 & 1.11274 & 0.71477 \\
\hline
\end{tabular}


$X_{\text {total }}=3.2873$ ), and shopping confidence $\left(\mathrm{X}_{\text {female }}=3.8421\right.$ vs. $\mathrm{X}_{\text {male }}=3.7361$, while $\left.\mathrm{X}_{\text {total }}=3.7937\right)$.

\section{Results}

The co linearity among the independent variables was examined through Tolerance and VIF. The Tolerance for each independent variable was more than 0.1 , and the VIF for each independent variable was less than 10 , which is the cut-off value beyond which multi-co linearity would be indicated; this implies no serious multi-co linearity.

The assumption of normality of the residuals was met, based on a histogram of the residuals showing that their distributions were normal, normal probability p-p plot showing that the residuals fell in a straight line, and normality residual of KormogorovSmirnov showing $\mathrm{p}=0.980>0.05$.
Assumptions of homoscedasticity were met. The residuals scatter plot showed a random pattern. A Glejser test was also conducted, and the results showed that all the significance probability was above 5 percent.

All independent variables were entered into the regression equation simultaneously. The analysis showed that 50.1 percent of variance in intention to shop for fashion products online was explained by the independent variables, with a significant $F$ value of 24.346 $(\mathrm{p}<0.001)$.

Results show that the effects of shopping enjoyment, price consciousness, in-home shopping tendency, consumer innovativeness, online purchase experience for fashion products, and gender, are significant on consumers' intention to shop for fashion products online. Furthermore, gender is marginally significant related to consumers' intention to shop for fashion products online. Surprisingly,

\section{Table 4. Multiple Regression Result}

(dependent variable=intention to shop for fashion products online)

\begin{tabular}{lccl}
\hline \multicolumn{1}{c}{ Variables } & Std.Beta & T & Sig. \\
\hline Brand/fashion consciousness & 0.040 & 0.720 & 0.472 \\
Shopping enjoyment & 0.150 & 2.297 & $0.023^{* *}$ \\
Price consciousness & 0.166 & 3.151 & $0.002^{*}$ \\
Convenience/time Consciousness & 0.003 & 0.066 & 0.947 \\
Shopping confidence & -0.007 & -0.135 & 0.893 \\
In-home shopping Tendency & 0.538 & 8.212 & $0.000^{*}$ \\
Consumer innovativeness & 0.118 & 2.259 & $0.025^{* *}$ \\
Purchase experience & 0.224 & 3.436 & $0.001 *$ \\
Gender & -0.101 & -1.659 & $0.099 * * *$ \\
Multiple R $_{\mathrm{R}^{2}}$ & 0.723 & & \\
Adjusted $\mathrm{R}^{2}$ & 0.523 & & \\
$\mathrm{~F}(\mathrm{df}=9$ ) & 0.501 & & \\
\hline
\end{tabular}

Notes: ${ }^{a}$ coded so that $1=$ female and $0=$ male

*Significant at $\mathrm{p}<0.01$ level; **Significant at $\mathrm{p}<0.05$ level; $* * *$ Significant at $\mathrm{p}<0.1$ level 
women tend to have lower intentions to shop for fashion products online compared to men. The result appears in Table 4.

Hypothesis 1 was not supported. The effect of brand/fashion consciousness on intention to shop for fashion products online was not significant. Hypothesis 2 was supported. The effect of shopping enjoyment on intention to shop for fashion products online was positively significant. Hypothesis 3 was also supported. The effect of shopping price consciousness on intention to shop for fashion products online was positively significant. Hypothesis 4 was not supported. The effect of convenience/time consciousness on intention to shop for fashion products online was not significant. Hypothesis 5 was not supported. The effect of shopping confidence on intention to shop for fashion products online was not significant. Hypothesis 6 was strongly supported. The effect of in-home shopping tendency on intention to shop for fashion products online was significant. Hypothesis 7 was supported. The effect of consumer innovativeness on intention to shop for fashion products online was significant. Hypothesis 8 was strongly supported. The effect of purchase experience on intention to shop for fashion products online was significant. Hypothesis 9 was not supported. Even though the result was marginally significant, but the result was contradicted with the hypothesis. Table 4 depicts the results of the regression analysis.

\section{Conclusion and Implications}

Result conclusions can be used by marketers or fashion online retailers to attract potential consumer and retain customers. Generally, research results can be used by business students, educators, marketers and retailers to understand Indonesian consumer potential buying power through the internet. Therefore, readers can have better information on deciding a target market in order to have effective marketing strategies. Beside that, research result can help retailer/online marketer to understand the importance of using several channels in selling the product, including the internet. Herewith are some advice for marketers or fashion online retailers in order to sell product through the internet:

In-home shopping tendency is a strong predictor for consumers' intention to shop for fashion products online. This shows that a consumer who likes to shop from home through telephone, catalog, email or internet has strong intention to shop online for fashion product. Consumers with this orientation prefer to shop from home and have high experience and comfort by using this method. Beside that, it is an oppurtunity for retailer who sells its product through catalog, specially fashion product, to adopt this method by making online stores. In fact, there is a possibility that consumers with this orientation will refuse technology, or did not have sufficient equipment and resources to perform online shopping, online retailers who wish to build customer base must actively pursue this segment in order to adopt fashion product online shopping.

Previous experiences on fashion product online shopping have been proven to influence intention to shop for fashion products online. This is an important asset that needs to be maintained by retailers or online stores, because implicitly such customers are already satisfied with their previous online activities. Marketers should retain the customer by improving service quality and maintaininggood relationships with every customer who already bought from their online store. Building long-term relationships 
with customers by good informal Customer Relationship Management (CRM) must be done by marketers. Especially relationships with profitable customers who often buy online and customers who like to buy product frequently. This process is related with the creation process and customer database management (Belch and Belch 2007). In order to fulfill customers' needs and wants, fashion clothes in online stores have to be ones that customers really like. Beside that, CRM can be used to established good relationship and interaction with customers who already have previous shopping experience in the online store.

The effect of price consciousness on intention to shop online shows that although the consumer who has an orientation on price did not mind to bear delivery cost, however, according to Seock and Bailey (2007), delivery cost can be an online shopping constraint for a consumer who is worried about price. Offering free delivery cost and return expense is an approach that can attract the consumer to online shopping. Consumers consider the free delivery cost as a value added point from online shopping. Therefore, the marketer should find ways to compensate delivery cost by considering price formulation strategy. Beside that, Vijayasarathy (2003) said that these shoppers like to gather and evaluate product information from multiple vendors before making a purchase decision. Therefore, the online retailer has to offer adequate information about their service and product by seting competitive prices or by frequently offerring promotion prices to attract potential consumers. This is a very important part in getting and maintaining consumers whose orientation is on price.

Consumers who are more orientated toward shopping enjoyment get pleasure from shopping online and spending time browsing fashion products. To attract consumers orientated on shopping enjoyment, online retailers can provide products with many variation and information services. Online retailers/ marketers should also put entertaintment features on their websites (online store), such as music, community, interactive networks (like chatting) so that customers can interact with the retailer or other customers, and testimonial or review about that online store from previous customers. Millenials (generation Y), as stated by Strauss and Frost (2009), use many media channels, instant messaging, email, chat-rooms, iPods or other MP3 player, P2P network, video games and virtual worlds. Therefore, online fashion retailers can enrich consumers' positive experiences in shopping online, and can boost consumer preference to shop online.

Research results show that consumers' innovativeness influences consumers' intention to shop for fashion products online. To attract and maintain inovativeness, online retailers should always provide something new and unique in website design or fashion product available in the online store.

Inconsistent results from the gender research show the differences between men and women in their intention to shop online; not only women- but men also have the intention to shop for fashion products online. Brashear et al. (2009) said that managers need to exercise caution in using only demographic variables to target online shoppers. Based on our observation, many online fashion retailers are only focusing on women consumers as their target market. For online retailers who think that fashion product is only enthused by women, they should start to focus on men by promoting and selling their product to male consumers.

Insights found in this research must be examined by online retailer becauses they can 
be opportunities for online retailers to attract and persuade consumers who have not tried new mediums of shopping, especially shopping for fashion products online. Although brand/fashion consciousness, convenience/ time consciousness and shopping confidence did not have significance for intention on shopping for fashion products online, there are some advices that can be pursued by retailers/online marketers.

Retailers/online marketers should follow fashion updates, and if they have enough capital, they should sell fashion products from famous brands and guarantee the originality of the product. Therefore, consumers who have orientation toward brand/fashion consciousness will be attracted to shop for fashion products online.

Further, as online consumers are time conscious, retailers/online marketers should use integrated technology in order to ease booking online, update inventory stock that will automatically be published in the website, and shorten delivery process and time. Therefore, consumers who focus on simplicity and time saving on shopping (convenience/time consciousness) will be interested in shopping fashion product online.

Retailers/online marketers also need to publish detail and size of fashion products, so that consumers can predict whether the product is exactly like they want or not. Beside that, consumers will be more comfortable if they can try the product first before buying it. Therefore, retailer/online marketer should allow consumer to return goods they have bought if the goods did not match consumer specification. This is carried on so that consumer have more certainty when buying the product, and minimize consumer's risk if the product is flawed, or not matched with desired shape, color and size. Beside that, if possible, online retailers should provide product display space (click and mortar store) so that consumer can see and try the product directly. Therefore, consumers who have orientation toward shopping confidence hopefully will be interested in shopping for fashion products online.

Based on the respondent demografic profile mentioned before, online shopping in general and online shopping for fashion products in particular, many consumer nowadays use internet. This evidence is strenghtened by interviews conducted by researchers of online store owners in Indonesia. The number of online shoppers is increasing, as proven by high online selling level. Related to that, traditional retailers should start to sell product through internet, as a part of technology adaptation and expansion of the market. Retailers can make personal paid websites (like "dotcom" or "dotnet"), or can use free blogs (like wordpress, blogspot), or by using popular social network and community (like facebook, multiply, kaskus). Online store type, content, website design should also be aligned with mission, vision and available resources.

The present research also leads to some future research agenda. Future research should add other independent variables in order to have whole representations of online shopping intention. For future research, researchers need to focus research on subjects who already have done online shopping in order to formulate further strategies in increasing service quality. This research describes a glance about payment method used by respondents who shop online. Results show that payment methods such as transfer by bank or ATM is commonly used by respondents. This might be due to, when research carried out, many online retailers which require payment through certain 
banks / ATM. Further empirical research should identify website characteristics and payment methods preferred by online consumers and their effects on online shopping intention. Further, research methods and probabilistic sampling selection technique might be needed to get more representative results on a specific locus or population of research subjects.

\section{References}

Alcañiz, E.B., C.R. Mafe, J.A. Manzano, and S.S. Blas. 2008. Influence of online shopping information dependency and innovativeness on internet shopping adoption. Online Information Review 32 (5): 648667.

Belch, G.E. and M.E. Belch. 2007. Advertising and Promotion, An Integrated Marketing Communications Perspective. $7^{\text {th }}$ Edition. New York: McGraw Hill Irwin.

Blake, B.F., K.A. Neuendorf, and C.M. Valdiserri. 2003. Innovativeness and variety of internet shopping. Internet Research 3: 156-164.

Brashear, T.G, V. Kashyap, M.D. Musante, N. Donthu. 2009. A profile of the internet shopper: Evidence from six countries. Journal of Marketing Theory and Practice 17: 267-281.

Brown, M., N. Pope, and K.Voges. 2003. Buying or browsing?: An exploration of shopping intentions and online purchase intention. European Journal of Marketing 37: 1666-1684.

Citrin, A.V., D.E. Sprott, S.N. Silverman and D.E. Stem. 2000. Adoption of internet shopping: The role of consumer innovativeness. Industrial management+Data Systems 100: 294-300.

Cooper, D.S. and P.S. Schindler. 2009. Business Research Methods (11 ${ }^{\text {th }}$ ed.). New York: McGraw Hill.

Garret, H. E. 1960. Statistics in Psychology and Education (5 ${ }^{\text {th }}$ ed.). New York: Longman.

Girard, T., P. Korgaonkar, and R. Silverblatt. 2003. Relationship of type of product, shopping orientations, and demographics with preference for shopping on the internet. Journal of Business and Psychology 18: 101-120.

Goldsmith, R. E., and L. R. Flynn. 1992. Identifying innovators in consumer product markets. European Journal of Marketing 26: 42-55.

Goldsmith, R. E. 2002. Explaining and predicting consumer intention to purchase over the internet: An exploratory study. Journal of Marketing Theory and Practice 10: 22-28.

Goldsmith, R. E., and L. R. Flynn. 2004. Psychological and behavioral drivers of online clothing purchase. Journal of Fashion Marketing and Management 8: 84-95.

Hurt, H. T., K. Joseph, and C. D. Cook. 1977. Scales for the measurement of innovativeness. Human Communication Research 5: 58-65.

Internetworldstats 1999. Internet usage in Asia. Retrieved 07/23/09 World Wide Web, bttp:// www.internetworldstats.com/stats3.btm\#asia

Jayawardhena, C., L. T. Wright, and C. Dennis. 2007. Consumers online: Intentions, orientations and segmentation. International Journal of Retail \& Distribution Management 35: 515-526.

Kim, E. Y., and Y. K. Kim. 2004. Predicting online purchase intentions for clothing products. European Journal of Marketing 38: 883-896. 
Kuhlmeier, D., and G. Knight. 2004. Antecedents to internet-based purchasing: A multinational study. International Marketing Review 22: 460-473.

Leavitt, C., and J. R. Walton. 1975. Development of a scale for innovativeness. In Mary Jan Schlinger (Ed.), Advances in Consumer Research 2: 545-554. Provo: Association of Consumer Research.

Leavitt, C., and J. R. Walton. 1988. Opennes of information processing as a moderator of message effects on behavior. Working paper. College of Business Administration, Ohio State University.

Limayem, M., M. Khalifa, and A. Frini. 2000. What makes consumers buy from internet? A longitudinal study of online shopping. IEE Transactions on Systems, Man and Cybernetics, Part A: Systems and Humans 30: 421-432.

Malhotra, N. K. 2007. Marketing Research: An Applied Orientation ( $5^{\text {th }}$ ed.). New Jersey: Prentice Hall.

Matthews, G., I. J. Deary, and M. C. Whiteman. 2003. Personality Traits (2 $2^{\text {nd }}$ ed.). Cambridge: Cambridge University Press.

Nielsen Global Online Survey. 2008. Trends in online shopping. A global Nielsen Consumer Report (February 2008) Retrieved 07/23/09 World Wide Web, http://th.nielsen.com/site/documents/ GlobalOnlineShoppingReportFeb08.pdf

Ranganathan, C. and S. Jha. 2007. Examining online purchase intentions in B2C e-commerce: Integrating the human-computer interaction, behavioral, and consumerist approaches. Information Resources Management Journal 20: 48-64.

Seock, Y. K., and L. R. Bailey. 2008. The influence of college students' shopping orientations and gender differences on online information searches and ourchase behaviours. International Journal of Consumer Studies 32: 113-121.

Seock, Y.K. 2003. Analysis of clothing website for young customer retention based on a model of customer relationship management via the internet. Unpublished dissertation. Faculty of theVirginia Polytechnic Institute and State University.

Shim, S., M. A. Eastlick, S. L. Lotz, and P. Warrington. 2001. An online prepurchase intentions model: The role of intention to search. Journal of Retailing 77: 397-416.

Stell, R., and N. Paden. 2002. Creating retail web sites for different consumer shopping orientations. Journal of Internet Commerce 1: 3-16.

Strauss, J., and R. Frost. 2009. E-Marketing. New Jersey: Pearson Education Inc.

Szymanski, D. M., and R. T. Hise. 2000. E-satisfaction: An initial examination. Journal of Retailing 76: 309322.

Tellis, G. J., E. Yin, and S. Bell. 2009. Global consumer innovativeness: Cross-country differences and demographic commonalities. Journal of International Marketing 17: 1-22.

Turban, E., D. King, J. McKay, P. Marshal, J. Lee, and D. Viehland. 2008. Electronic Commerce 2008: A Managerial Perspective. New Jersey: Prentice Hall.

Vijayasarathy, L. R. 2002. Product characteristics and internet shopping intentions. Internet Research: Electonic Networking Applications and Policy 12: 411-426.

Vijayasarathy, L. R. 2003. Shopping orientations, product types and internet shopping intentions. Electronic Markets 13: 67-79. 